\title{
CRYOPRESERVED HOMOGRAFT VALVES IN THE PULMONARY POSITION: RISK ANALYSIS FOR INTERMEDIATE-TERM FAILURE
}

Kazuo Niwaya, MDa

Christopher J. Knott-Craig, MDa

Mary M. Lane, $\mathrm{PhD}^{\mathrm{a}}$

K. Chandrasekaren, $\mathrm{MD}^{\mathrm{b}}$

Edward D. Overholt, $\mathrm{MD}^{\mathrm{c}}$

Ronald C. Elkins, MD ${ }^{\mathrm{a}}$
Objective: The purpose of this study was to examine the durability of cryopreserved homografts used to replace the "pulmonary" valve and to identify factors associated with their late deterioration. Methods: We reviewed our entire experience (1985-1997) with 331 survivors in whom cryopreserved homograft valves (pulmonary, $n=304$; aortic, $\mathbf{n}=27$ ) were used to reconstruct the pulmonary outflow tract. Median age was 14 years (range, 2 days-62 years). Operations included Ross operation ( $n=259)$, tetralogy of Fallot $(n=41)$, truncus arteriosus $(n=14)$, Rastelli operation $(n=11)$, and others $(n=6)$. Median follow-up was 3.8 years (range, 0.2-11.2 years); late echographic follow-up was complete for $97 \%$ of patients. Homograft failure was defined as the need for explantation and valve-related death; homograft dysfunction was defined as a pulmonary insufficiency grade 3/4 or greater and a transvalvular gradient of $40 \mathrm{~mm} \mathrm{Hg}$ or greater. Results: Homograft failure occurred in 9\% (30 of 331 patients; Kaplan-Meier); freedom from failure was $82 \% \pm 4 \%$ at 8 years. Homograft dysfunction occurred in $12 \%$ (39 of 331 patients), although freedom from dysfunction was $76 \% \pm 4 \%$ at 8 years. For aortic homografts, this was $56 \% \pm 11 \%$, compared to $80 \% \pm 4 \%$ for pulmonary homografts $(P=.003)$. For patients aged less than 3 years $(n=38)$, this was $51 \% \pm 12 \%$, compared with $87 \% \pm 4 \%$ for older patients $(P=\mathbf{0 0 0 1})$. By multivariable analysis, younger age of homograft donors, non-Ross operation, and later year of operation were associated with homograft failure; younger age of homograft donors, later year of operation, and use of an aortic homograft were associated with homograft dysfunction. Conclusions: Homograft valves function satisfactorily in the pulmonary position at mid-term follow-up. The pulmonary homograft valve appears to be more durable than the aortic homograft valve in the pulmonary position. (J Thorac Cardiovasc Surg 1999;117:141-7)
$T^{\mathrm{h}}$ he use of homograft valves to reconstruct the right ventricular outflow tract was introduced by Ross and Somerville $^{1}$ in 1966. Refinements in the harvesting, cryopreservation, and distribution of homografts have paral-

From the Sections of Thoracic and Cardiovascular Surgery, ${ }^{\mathrm{a}}$ Cardiology, ${ }^{\mathrm{b}}$ and Pediatric Cardiology, ${ }^{\mathrm{c}}$ University of Oklahoma Health Sciences Center, Oklahoma City, Okla.

Read at the Seventy-eighth Annual Meeting of The American Association for Thoracic Surgery, Boston, Mass, May 3-6, 1998.

Received for publication May 8, 1998; revisions requested June 5, 1998; revisions received Sept 22, 1998; accepted for publication Sept 28, 1998.

Address for reprints: Christopher J. Knott-Craig, MD, Section of Thoracic and Cardiovascular Surgery, University of Oklahoma Health Sciences Center, Post Office Box 26901, Oklahoma City, OK 73190 .

Copyright $\odot 1999$ by Mosby, Inc.

$0022-5223 / 99 \$ 8.00+0 \quad \mathbf{1 2 / 6 / 9 4 9 6 9}$ leled increased enthusiasm among thoracic surgeons for homografts as replacement valve conduits for the reconstruction of the pulmonary outflow ventricle. ${ }^{2-5}$

Although the results of cryopreserved homograft valves for reconstruction of the right ventricular outflow tract in complex congenital heart diseases has been reported by several previous authors, ${ }^{5-13}$ reports on medium-term follow-up are still uncommon. ${ }^{14,15} \mathrm{We}$ reviewed our experience since 1985 with 331 patients, including Ross operations, in whom cryopreserved homografts were used in the "pulmonary" position to examine the risk factors associated with homograft failure over the mid-term follow-up period.

\section{Methods}

A homograft was first used to reconstruct the pulmonary outflow tract at the Oklahoma University Health Sciences 
Table I. Diagnosis and homograft outcome

\begin{tabular}{lcccc}
\hline Operation & $\begin{array}{c}\text { No. } \\
\text { of patients }\end{array}$ & $\begin{array}{c}\text { Valve related } \\
\text { late death }\end{array}$ & $\begin{array}{c}\text { Reoperation } \\
\text { of conduit }\end{array}$ & $\begin{array}{c}\text { Obstruction } \\
(>40 \mathrm{~mm} \mathrm{Hg})\end{array}$ \\
\hline $\begin{array}{l}\text { Ross operation } \\
\text { Complex tetralogy of Fallot/ }\end{array}$ & 259 & 0 & 14 & 24 \\
$\quad$ pulmonary atresia with VSD & 41 & 1 & 7 & 6 \\
Truncus arteriosus & 14 & 1 & 6 & 5 \\
Transposition of great vessels & 11 & 0 & 3 & 4 \\
Other & 6 & 0 & 0 & 0 \\
\hline
\end{tabular}

$V S D$, Ventricular septal defect.

Center in November 1985. Through January 1997, this reconstruction was performed in 369 patients, with 38 early deaths. The 331 patients surviving to hospital discharge form the basis of this review. Patients who had homograft tissue used only as a nonvalved patch are not included. In all cases the homografts were prepared by CryoLife Inc (Kennesaw, Ga).

Patient characteristics. The median age at operation of the 237 male patients and 94 female patients was 14 years (range, 2 days-62 years). The homografts were used as part of the following operations: Ross operation $(n=259 ; 78 \%)$, tetralogy of Fallot or pulmonary atresia with ventricular septal defect $(n=41 ; 13 \%)$, truncus arteriosus $(n=14 ; 4 \%)$, Rastelli-type operation $(n=11 ; 3 \%)$, and others $(n=6 ; 2 \%)$. One hundred eighty patients (54\%; 180 of 331 patients) had undergone previous cardiac operations, $46(14 \%)$ of which were on the pulmonary outflow tract. Twenty-one patients had a previous right ventricular outflow tract (RVOT) reconstruction with a homograft, and 5 patients had a previous aortic valve replacement with a homograft.

Homograft characteristics. Twenty-seven aortic homografts and 304 pulmonary homografts were used. The median age of the homograft donors was 19 years (range, 5 months -58 years). The homografts varied in size from 10 to $30 \mathrm{~mm}$ in diameter (mean, $22.4 \pm 4.1 \mathrm{~mm}$ ). The mean time period between harvesting and implantation of the homografts was $7.7 \pm 8.4$ months (duration of cryopreservation).

Patient follow-up. The medical records of the 331 patients included in this study were reviewed to obtain detailed information on the operation, previous intervention, subsequent need for operative treatment, and physical status. Homograft status was evaluated by 2-dimensional, color flow, and continuous wave Doppler echocardiography. The pressure gradient across the RVOT was measured by peak instantaneous Doppler velocity with pulse and continuous wave Doppler techniques. Peak flow velocities were obtained from the Doppler tracings and converted to peak instantaneous gradients by a simplified Bernoulli test. Homograft regurgitation was graded subjectively as 0 to 4 , with $3+$ or greater representing significant regurgitation. Follow-up ranged from 1 month to 11.2 years (median follow-up, 3.8 years).

Definitions of end points. Homograft failure was defined as all reoperations involving explantation of the homograft and all valve-related deaths. ${ }^{12,15}$ Moderate (3+) pulmonary insufficiency and transvalvular gradient greater than $40 \mathrm{~mm}$
Hg were defined as homograft dysfunction. ${ }^{12,16}$ The distribution of outcomes with diagnosis groups is shown in Table I. There were relatively few patients at risk of conduit failure or dysfunction beyond 8 years of follow-up; hence most data are reported as 8-year follow-up.

Statistical analysis. All analyses were performed with SAS System software (version 6.10; SAS Institute, Cary, $\mathrm{NC}$ ). Mean values are presented \pm 1 SD. Between-group differences of continuous variables were analyzed with analysis of variance methods, and $\chi^{2}$ or Fisher's exact methods were used to test differences between proportions. Actuarial estimates of freedom from postoperative events were accomplished with Kaplan-Meier methods, and $P$ values for differences between distributions were obtained by log-rank testing. Event-free rates are presented with $\pm 1 \mathrm{SE}$ of the estimate. Potential risk factors evaluated in multivariable analysis of conduit failure or dysfunction included age, weight, sex, date of operation, diagnosis, previous cardiac operations, previous homograft, type of homograft (either aortic or pulmonary), size of homograft, duration of cryopreservation, and age of homograft donor. The analyses were performed with Cox proportional hazards regression. A forward stepwise selection method was used to add variables to the model, requiring significance at $P<.10$ for entry and $P<.05$ for retention in the model. Early death was defined as hospital death or death within 30 days after operation.

\section{Results}

The late mortality rate was $4 \%$ (13 of 331 patients). Of these, only 2 deaths were valve-related, yielding a late valve-related mortality rate of $1 \%$. Both late deaths were related to reoperation, the first occurring in a 2year-old child who underwent double homograft replacement for truncus arteriosus as a neonate, and the second in a 3-year-old child with pulmonary atresia and ventricular septal defect who died 2 months after the operation of mediastinitis after replacement of the homograft. The 11 nonvalve-related deaths resulted from chronic heart failure $(\mathrm{n}=5)$, aspiration pneumonia $(n=2)$, reoperation for unrelated defects, and other causes such as cerebral aneurysm, myocardial infarction, suicide, and accidents. 


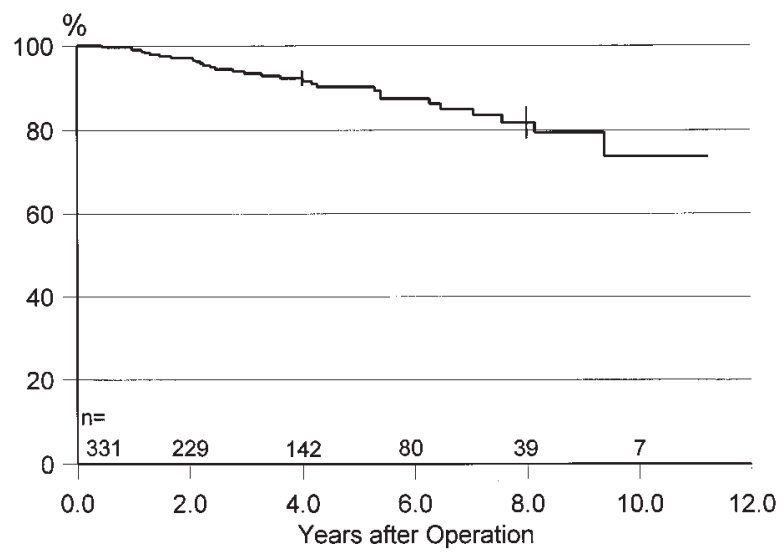

Fig 1. Kaplan-Meier freedom from failure (explantation of homograft or valve-related death). Vertical bars represent the $70 \%$ confidence interval.

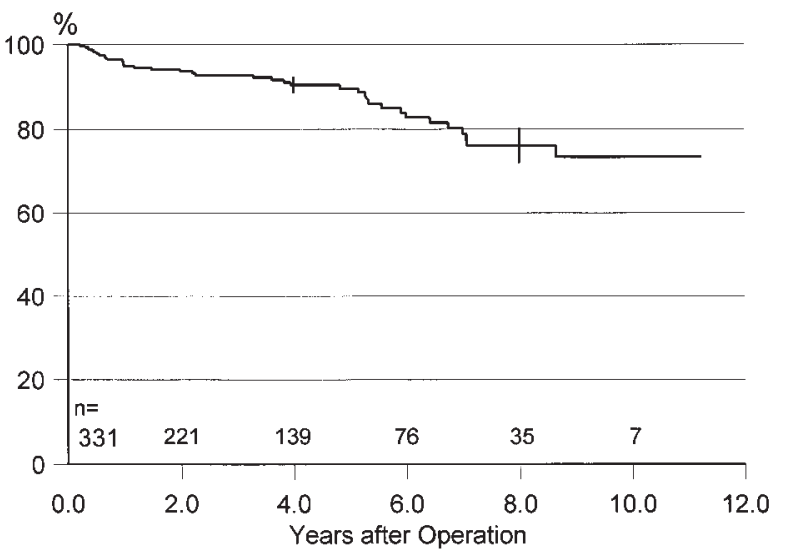

Fig 2. Kaplan-Meier freedom from dysfunction ( $>40 \mathrm{~mm} \mathrm{Hg}$ homograft obstruction and/or 3-4+ regurgitation). Vertical bars represent the $70 \%$ confidence interval.

Table II. Risk factors for homograft failure

\begin{tabular}{lccc}
\hline Characteristic & Univariable $\mathrm{P}$ value & Multivariable $\mathrm{P}$ value & $\begin{array}{c}\text { Multivariable odds ratio } \\
\text { (95\% confidence interval) }\end{array}$ \\
\hline Donor age, $<5$ y & .0001 & .0001 & $7.8(3.3-18.2)$ \\
Later year of operation & .20 & .0343 & $1.3(1.1-1.6)$ \\
Non-Ross operation & .0001 & .0058 & $3.4(1.4-8.1)$ \\
Age of patient (younger) & .008 & - & - \\
Homograft diameter (smaller) & .001 & - & - \\
Aortic homograft & .003 & - & - \\
\hline
\end{tabular}

Thirty-nine patients had evidence of homograft dysfunction; of those, 29 have had the homografts replaced. One additional patient had the homograft replaced after an inadvertent injury during an unrelated cardiac operation. Forty patients (12\%) therefore had either homograft dysfunction or conduit failure.

Homograft failure. Homograft failure occurred in 30 patients (9\%; 30 of 331 patients). These include the 2 valve-related deaths. The indications for explanting the homografts were conduit stenosis in 23 patients, homograft insufficiency associated with distal pulmonary artery stenosis in 3 patients, homograft hood aneurysms in 2 patients, technical error in 1 patient, and injury of the homograft during repair of an autograft in 1 patient. Kaplan-Meier freedom from homograft failure was $90 \% \pm 2 \%$ at 5 years and $82 \% \pm 4 \%$ at 8 years (Fig 1). This was $89 \% \pm 4 \%$ for patients having a Ross operation at 8 years versus $62 \% \pm 9 \%$ for all other patients $(P=.0001)$. At 8 years, freedom from failure was $86 \% \pm 4 \%$ for pulmonary homografts versus $61 \% \pm 11 \%$ for aortic homografts $(P=.003)$.

By univariate analysis, younger age of recipients, smaller homograft size, and aortic homografts were significant risk factors; however, by multivariable analysis only younger donor age (less than 5 years), later year of operation, and non-Ross operation were associated with homograft failure (Table II).

Homograft dysfunction. Thirty-nine patients had evidence of significant homograft obstruction or incompetence (gradient of $40 \mathrm{~mm} \mathrm{Hg}$ or more and/or 3$4+$ regurgitation for an incidence of homograft dysfunction of 12\%; 39 of 331 patients). Of these, 29 have had the homografts replaced and are therefore also included among the homograft failures. Kaplan-Meier freedom from homograft dysfunction was $90 \% \pm 2 \%$ at 5 years and $76 \% \pm 4 \%$ at 8 years (Fig 2). This was $84 \%$ $\pm 4 \%$ for patients having a Ross operation versus $53 \%$ $\pm 10 \%$ for all other patients ( $P=.006$; Fig 3$)$. KaplanMeier freedom from dysfunction at 8 years was $80 \% \pm$ $4 \%$ for pulmonary homografts versus $56 \% \pm 11 \%$ for aortic homografts $(P=.006$; Fig 4). In 293 patients older than 3 years, Kaplan-Meier freedom from dysfunction was $81 \% \pm 4 \%$ at 8 years, compared with $42 \%$ $\pm 14 \%$ for 38 younger patients $(P=.005$; Fig 5$)$. For patients aged 18 to 40 years, the freedom from homograft dysfunction at 8 years was $82 \%$. 


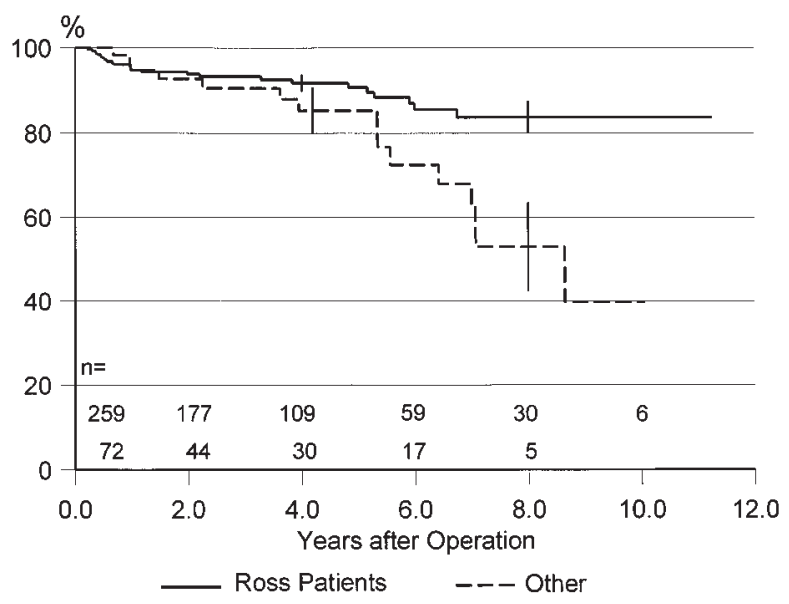

Fig 3. Kaplan-Meier freedom from homograft dysfunction, stratified according to type of procedure $(P=.006)$. Vertical bars represent the $70 \%$ confidence interval.

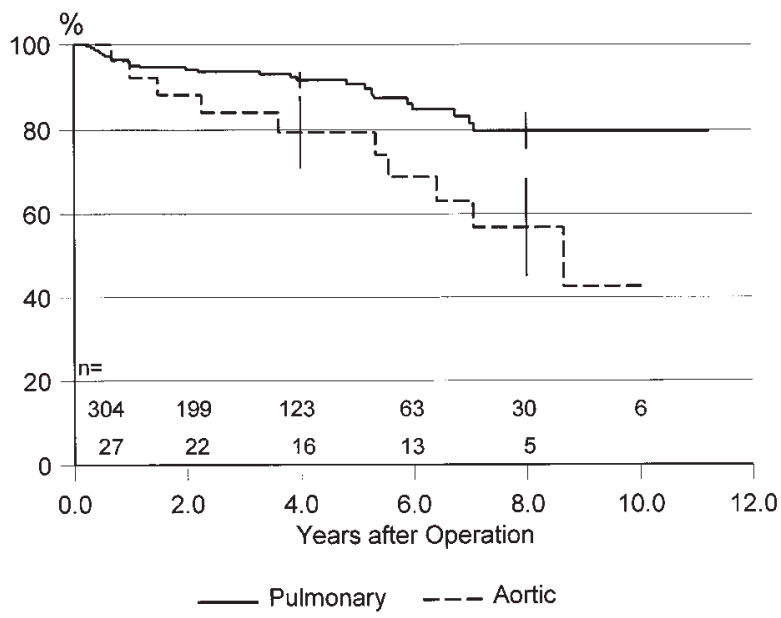

Fig 4. Kaplan-Meier freedom from homograft dysfunction, stratified according to homograft materials $(P=.006)$. Vertical bars represent the $70 \%$ confidence interval.

Although non-Ross operation, use of an aortic homograft, and younger patient age were associated with homograft failure by univariate analysis, by multivariable analysis the use of an aortic homograft, younger donor age, and later year of operation were the only risk factors for homograft dysfunction (Table III). Even when recipient age was forced into the model, donor age was still a highly significant risk factor, although recipient age was not.

\section{Discussion}

With the increased availability of homografts made possible by cryopreservation ${ }^{5,18,19}$ and the development

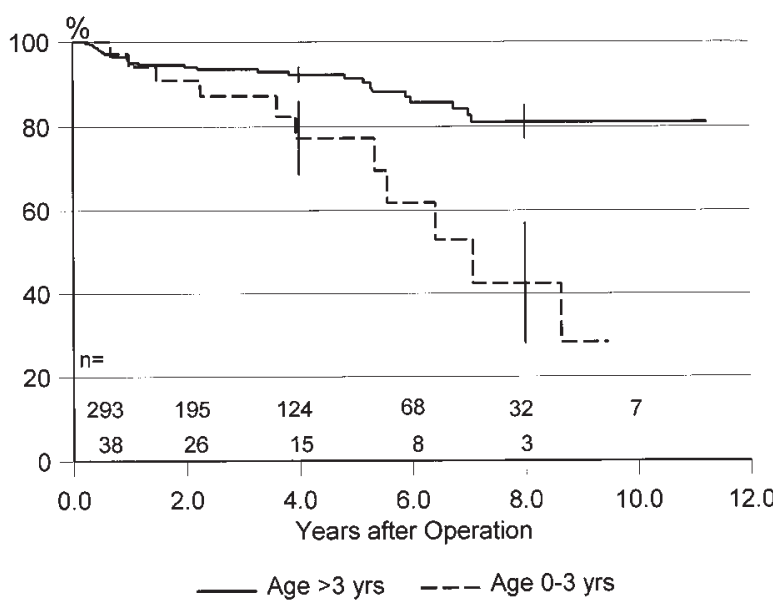

Fig 5. Kaplan-Meier freedom from homograft dysfunction, stratified according to age $(P=.005)$. Vertical bars represent the $70 \%$ confidence interval.

of valve banks, there has been renewed interest in the use of the valved homograft to reconstruct the pulmonary outflow tract. By the mid-1980s, cryopreserved homograft valves were considered by many surgeons to be the valve conduit of choice for replacement of the pulmonary valve, because they seemed to have many advantages over alternative prosthetic valved conduits. ${ }^{2,5-7,12-15,20,21}$ These advantages include (1) technical ease of implantation because they are soft and mold easily with the patient's cardiac tissue ${ }^{22}$ resulting in better hemostasis in complex operations ${ }^{21,23}$; (2) better hemodynamics than porcine-valved Dacron conduits, which improves right ventricular function after the operation ${ }^{5,7,21,23-25}$; and (3) the branches of the homografts may be used to patch distal pulmonary artery stenoses. ${ }^{7,20,26}$

As the Ross operation (pulmonary autograft replacement of the aortic valve) has gained popularity, so too has the use of the pulmonary homograft to reconstruct the RVOT in this patient population. ${ }^{3,4}$ In fact, most of our patients fall into this category. Patients having a Ross operation generally have normal pulmonary vascular anatomy and resistance, and this may account for the better late results with pulmonary homografts in these patients. In contrast, many patients with other forms of congenital heart disease have distal pulmonary artery branch stenoses or high pulmonary vascular resistance, both of which may affect the durability of the homografts. ${ }^{7,27,28}$ In fact, younger recipient age, $, 12,13$ use of the aortic homograft, ${ }^{7,12,15}$ small homograft valve size ${ }^{13}$ long aortic crossclamp time at operation, ${ }^{15}$ pulmonary hypertension, ${ }^{27}$ and distal pulmonary artery disease ${ }^{7,28}$ have all previously been identified as risk factors associated with medium-term fail- 
Table III. Risk factors for homograft dysfunction

\begin{tabular}{lccc}
\hline Characteristic & Univariable $\mathrm{P}$ value & Multivariable $\mathrm{P}$ value & $\begin{array}{c}\text { Multivariable odds ratio } \\
\text { (95\% confidence interval) }\end{array}$ \\
\hline Donor age, $<5$ y & .0001 & .0001 & $8.8(4.1-19.0)$ \\
Later year of operation & .018 & .0343 & $1.5(1.2-1.8)$ \\
Aortic homograft & .006 & .0022 & $3.9(1.6-10.0)$ \\
Age of patient (younger) & .02 & - & - \\
Homograft diameter (smaller) & .0001 & - & - \\
Non-Ross procedure & .003 & - & - \\
\hline
\end{tabular}

ure of cryopreserved homografts in the RVOT. Young age at operation seems to be a common risk factor of the homograft failure, ${ }^{8,12,13}$ because this closely relates to the size of the homograft implanted and therefore to the age of the homograft donor. In addition, infants generally triple their size within 18 months, thus outgrowing their homograft more quickly than older children. This was confirmed in our univariate analysis of homograft dysfunction by age (Fig 5). However, in our multivariable analysis young patient age ( $<3$ years) was not associated with an increased risk of failure.

It is interesting to speculate that younger donor age is somehow related to increased immunogenicity of the homograft and that this may have negatively affected the late function of the homograft; the strong association of young donor age in our multivariable analysis adds support to this theory. Furthermore, severe homograft valved conduit stenosis developed within the first postoperative year in a few patients who underwent the Ross operation. ${ }^{29,30}$ The stenosis was usually located just above the commissures in the proximal portion of the homograft conduit. One additional patient experienced the development of rapid homograft deterioration within 4 months of reoperation for such an obstruction. These findings lend some credence to a possible immune-mediated response, ${ }^{17}$ although this speculation remains unproved. ${ }^{31-33}$ It is possible that some form of perioperative immunosuppression may be beneficial in these high-risk patients. ${ }^{17,30}$

Although aortic homografts have been used to reconstruct the pulmonary outflow tract for many years, $2,5,20$ the aortic valves have been considered to be susceptible to higher rates of calcification in the pulmonary position than the pulmonary homograft valves because of their higher elastin and intrinsic calcium content. ${ }^{34}$ The Mayo Clinic group ${ }^{12}$ recently reported that, in the pulmonary position, the pulmonary homograft was more durable than the aortic homograft valves with less calcification and obstruction, especially among children 4 years of age or younger. Our study, in which the aortic homograft was shown to be an independent risk factor for homograft dysfunction, confirms their findings.
Technical factors such as hood extension of the proximal suture line, anatomic versus nonanatomic placement of the conduit, and compression of the conduit behind the sternum may all be important determinants of homograft longevity. ${ }^{12}$ These were not specifically analyzed in our study because of the limited number of such procedures. We did not identify individual cardiac diagnoses or operative procedures within the non-Ross operation group of patients as significant risk factors. Rather, all the congenital cardiac disease subgroups were collectively associated with increased risk compared with the patients having a Ross operation.

Later year of operation was associated with increased risk both of homograft failure and homograft dysfunction. We are unable to explain this finding within the context of our present study but are further analyzing patient factors and preservation and biocompatibility factors in an attempt to resolve this dilemma.

In summary, for RVOT reconstruction, non-Ross procedure, cryopreserved aortic homograft valves, homograft valves from younger donors, and later operation were significant risk factors for homograft failure. The cryopreserved pulmonary homograft valve appears to be the conduit of choice for RVOT reconstruction.

The authors thank Carolyn McCue, RN, and Mark Jones, PA, who helped with patient review and follow-up, and Karen Dale, who helped with the preparation of this paper.

\section{REFERENCES}

1. Ross DN, Somerville J. Correction of pulmonary atresia with a homograft aortic valve. Lancet 1966;2:1446-7.

2. Kay H, Ross DN. Fifteen years' experience with the aortic homograft: the conduit of choice for right ventricular outflow tract reconstruction. Ann Thorac Surg 1985;40:360-4.

3. Matsuki O, Okita Y, Almeida RS, McGoldrich JP, Hooper TL, Robles A, et al. Two decades' experience with aortic valve replacement with pulmonary autograft. J Thorac Cardiovasc Surg 1988;95:705-11.

4. Elkins RC, Knott-Craig CJ, Ward KE, Lane MM. The Ross operation in children: 10-year experience. Ann Thorac Surg 1998; 65:496-502.

5. Kirklin JW, Blackstone EH, Maehara T, Pacifico AD, Kirklin JD, Pollock S, et al. Intermediate-term fate of cryopreserved allograft 
and xenograft valved conduits. Ann Thorac Surg 1987;44:598606.

6. Hawkins JA, Bailey WW, Dillon T, Schwartz DC. Midterm results with cryopreserved allograft valved conduits from the right ventricle to the pulmonary arteries. J Thorac Cardiovasc Surg 1992;104:910-6.

7. Albert JD, Bishop DA, Fullerton DA, Campbell DN, Clarke DR. Conduit reconstruction of the right ventricular outflow tract: lessons learned in a twelve-year experience. J Thorac Cardiovasc Surg 1993;106:228-36.

8. Chan KC, Fyfe DA, McKay CA, Sade RM, Crawford FA. Right ventricular outflow reconstruction with cryopreserved homografts in pediatric patients: intermediate-term follow-up with serial echocardiographic assessment. J Am Coll Cardiol 1994;24: 483-9.

9. Salim MA, DiSessa TG, Alpert BS, Arheart KL, Novick WM, Watson DC. The fate of homograft conduits in children with congenital heart disease: an angiographic study. Ann Thorac Surg 1995;59:67-73.

10. Daenen W, Narine K, Goffin Y, Gewillig M. Right ventricular outflow reconstruction with homografts. Eur J Cardiothorac Surg 1995;9:448-52.

11. Cleveland DC, Williams WG, Razzouk AJ, Trusler GA, Rebeyka IM, Duffy L, et al. Failure of cryopreserved homograft valved conduits in the pulmonary circulation. Circulation 1992;86 (Suppl):II150-3.

12. Bando K, Danielson GK, Schaff HV, Mair DD, Julsrud PR, Puga FJ. Outcome of pulmonary and aortic homografts for right ventricular outflow tract reconstruction. J Thorac Cardiovasc Surg 1995;109:509-18.

13. Stark J, Bull C, Stajevic M, Jothi M, Elliot M, de Leval M. Fate of subpulmonary homograft conduits: determinants of late homograft failure. J Thorac Cardiovasc Surg 1998;115:506-16.

14. Baskett RJ, Ross DB, Nanton MA, Murphy DA. Factors in the early failure of cryopreserved homograft pulmonary valves in children: preserved immunogenicity. J Thorac Cardiovasc Surg 1996;112:1170-9.

15. Daenen W, Gewillig M. Factors influencing medium-term performance of right-sided cryopreserved homografts. J Heart Valve Dis 1997;6:347-53.

16. Edmunds LH, Clark RE, Cohn LH, Grunkemeier GL, Miller DC, Weisel RD. Guidelines for reporting morbidity and mortality after cardiac valvular operations. Ann Thorac Surg 1996;62:932-5.

17. Ward KE, Elkins RC, Overholt ED, Knott-Craig CJ, Razook JD, Lane MM, et al. Evaluation of cryopreserved homografts in right ventricular outflow tract after the Ross procedure: intermediateterm follow up. J Heart Valve Dis 1997;6:130-3.

18. O'Brien MF, Stafford EG, Gardner MAH, Pohlner PG, Tesar PJ, Cochrane AD, et al. Allograft aortic valve replacement: long-term follow up. Ann Thorac Surg 1995;60:S65-70.

19. Angell JD, Christopher BS, Hawtrey O, Angell WM. A fresh, viable human heart valve bank: sterilization, sterility testing, and cryogenic preservation. Transplant Proc 1976;8(suppl):139-47.

20. Fontan F, Choussat A, Deville C, Doutremepuich C, Coupillaud J, Vosa C. Aortic valve homografts in the surgical treatment of complex cardiac malformations. J Thorac Cardiovasc Surg 1984;87:649-57.

21. Sano S, Karl TR, Mee RBB. Extracardiac valved conduits in the pulmonary circuit. Ann Thorac Surg 1991;52:285-90.

22. Vesely I, Gonzales-Lavin L, Graf D, Boughner D. Mechanical testing of cryopreserved aortic allografts. J Thorac Cardiovasc Surg 1990;99:119-23.
23. Lamberti JJ, Mainwaring RD, Billman GF, Hopkins BA, George L, Mathewson JW, et al. The cryopreserved homograft valve in the pulmonary position: mid-term results and technical considerations. J Card Surg 1991;6(suppl):627-32.

24. Bove EL, Beekman RH, Snider AR, Callow LB, Underhill DJ, Rocchini AP, et al. Repair of truncus arteriosus in the neonate and young infant. Ann Thorac Surg 1989;47:499-506.

25. Hopkins RA. Right ventricular outflow tract reconstructions: the role of valves in the viable allograft era. Ann Thorac Surg 1988; 45:593-4.

26. Burczynski PL, McKay R, Arnod R, Mitchell DR, Sabino GP. Homograft replacement of the pulmonary bifurcation. J Thorac Cardiovasc Surg 1989;98:623-31.

27. Kadoba K, Armiger LC, Sawatari K, Jonas RA. Mechanical durability of pulmonary allograft conduits at systemic pressure: angiographic and histologic study in lambs. J Thorac Cardiovasc Surg 1993;105:132-41.

28. DeLeon SY, Tuchek JM, Bell TJ, Hofstra J, Vitullo DA, Quinones JA, et al. Early pulmonary homograft failure from dilatation due to distal pulmonary artery stenosis. Ann Thorac Surg 1996;61: 234-7.

29. Elkins RC, Lane MM, McCue CM. Pulmonary autograft reoperation: incidence and management. Ann Thorac Surg 1996;62: 450-5.

30. Ross DN. Evolution of the homograft valve. Ann Thorac Surg 1995;59:565-7.

31. Hogan P, Duplock L, Green M, Smith S, Gall KL, Frazer IH, et al. Human aortic valve allografts elicit a donor-specific immune response. J Thorac Cardiovasc Surg 1996;112:1260-7.

32. Hoekstra F, Knoop C, Vaessen L, Wassenaar C, Jutte N, Bos E, et al. Donor-specific cellular immune response against human cardiac valve. J Thorac Cardiovasc Surg 1996;112:281-6.

33. Hoekstra F, Witvliet M, Knoop C, Akkersdijk G, Jutte N, Bogers A, et al. Donor-specific anti-human leukocyte antigen class I antibodies after implantation of cardiac valve allografts. J Heart Lung Transplant 1997;16:570-2.

34. Livi U, Ardulla A-K, Parker R, Olsen EJ, Ross DN. Viability and morphology of aortic and pulmonary homografts: a comparative study. J Thorac Cardiovasc Surg 1987;93:755-60.

\section{Discussion}

Dr Gordon K. Danielson (Rochester, Minn). Most of the conclusions from this study are in agreement with those of our recent review of a similar-sized series reported in 1995 and those of other recent reviews of homografts. These findings include the fact that aortic homografts do calcify and become obstructed faster than pulmonary homografts.

However, when we reanalyzed our data and included all reasons for conduit replacement such as false aneurysms of the anastomotic sites, nearly all of which were associated with pulmonary homografts in patients with right ventricular hypertension, we found that there really was no difference in late failure at least through 4 years. So, the failure rate depends a little bit on one's definition of homograft failure.

You presented an interesting new set of data that showed that the incidence of homograft failure was less in patients after the Ross procedure as compared with other operations for congenital cardiac anomalies. This may explain, in part, 
the difference between the behavior of pulmonary homografts in our series compared with yours. Can you discuss the reasons why there is a difference in homograft failure between Ross and non-Ross operations?

There was no mention of balloon dilatation or stenting for homograft stenosis. This does seem to be a problem in some series. Was this done in any patients in your series and were such patients included as having homograft dysfunction?

The pulmonary autograft procedure remains controversial. In some excellent institutions, few if any such operations are currently performed especially in adults, because of the additional complexity of the procedure, because of the fact that 2 cardiac valves are put at risk instead of 1 , and, until recently with reports such as yours, because of the lack of data regarding late results of cryopreserved homografts in the pulmonary position. In other excellent institutions, the Ross procedure is a treatment of choice.

In view of recent reports of up to $90 \%$ or more of patients being free of reoperation for homograft failure 10 years after isolated homograft replacement of the aortic valve (especially patients treated with the current trend toward intraluminal cylinder or root replacement rather than use of a scalloped homograft), together with the $16 \%$ incidence of incompetent right ventricle-pulmonary artery homografts, homograft dysfunction, or homograft replacement at 8 years after the Ross procedure in your series, what are your current thoughts on the relative role of the Ross procedure in the treatment of aortic valve disease?

Dr Knott-Craig. With regard to the first question, that the failure rate and the structural deterioration rate is lower in patients who have Ross operations versus the other pathologies relates mainly to the fact that patients having isolated aortic valve replacement have normal distal pulmonary artery vasculature both in terms of pulmonary hypertension and in distal embolization problems.

In terms of balloon dilatation of the pulmonary homografts, this is not a favored technique in our institution. We have a very low threshold to replace homografts rather than have the cardiologists address them either with stents or balloon dilatations.

The question about the Ross operation is a little beyond the scope of my presentation. However, generally speaking, when any new operation is adopted by a wide variety of surgeons with varying expertise, the indications become diluted and complications can be anticipated, resulting in reopera- tions on the aortic valve or pulmonary valve. However, the alternatives available in young children and infants remain limited, and this is the area where the Ross operation has its greatest aptitude.

Dr Charles A. Yankah (Berlin, Germany). The group in Berlin has done over 300 homograft implantations in the RVOTs. Since 1986 we have known that the pulmonary homograft is the valve of choice and that it is a better alternative. The question is whether a viable homograft will be suitable for children, especially, because our immunologic problem with homovital cryopreserved homografts, which were used mainly in infants and in children, subsequently yielded no satisfactory results. The pathologic condition of the homograft explants was either at the valvular level with degenerative stenosis or at the supravalvular level. Did you observe such pathologic changes with regard to multilevel stenosis, which we observed especially in our children? With regard to your experience, would you derive any suggestion for preferring a nonviable homograft in infants and children, rather than homovital or viable homografts?

Dr Knott-Craig. If one tries to define why later year of operation was a risk factor for dysfunction or failure and why younger donor age was a risk factor for both failure and dysfunction, there are limited alternative explanations. We think that immunogenicity is important and is more important the younger the patient. We tried to define this better in our analysis by looking at the duration of cryopreservation from harvesting to the implantation of the homograft. Although this seemed important, it never stood up in the multivariate analysis as an independent risk factor for failure. We have also seen early homograft failure particularly in young children. Currently, if this should occur within 1 year of the operation, we put the patient on high-dose ibuprofen or steroids for the first 3 months after the operation. So yes, I think viability of the cells is an issue in children, but we have not yet defined how to deal with it.

Dr Lawrence H. Cohn (Boston, Mass). I have one very short question. This is a fantastic series. For those of us who do this in young adults, can you give us any estimate of the freedom of homograft dysfunction at 8 years in patients who are 18 years or older when you do this operation?

Dr Knott-Craig. In the age group 18 to 40 years, the freedom from homograft dysfunction is about $82 \%$ at 8 years, not statistically different from the 0 - to 18 -year age group. 